Tumbool Camel Research Centre (TCRC),

Animal Resources Research Corporation,

Ministry of Animal Resources and Fisheries, Sudan

\title{
BODY MEASUREMENTS OF SOME SUDANESE CAMEL ECOTYPES (CAMELUS DROMEDARIUS) IN BUTANA AREA-SUDAN \\ (With 2 Tables)
}

\author{
By \\ M.H.M. ELBASHIR; B.E. ABDEL-AZIZ and I.A. ISHAG* \\ * Department of Animal Production, Faculty of Agriculture, \\ University of Sinnar, Sudan. \\ (Received at 18/5/2011)
}

\section{SUMMARY}

The aim of the study was to phenotypic characterize the two Sudanese ecotypes according to their phenotypic measurements. Body measurements data were obtained on 256 camels from two Sudanese ecotypes (Arabi and Anaffi type). The data collected from central of Butana area-Sudan. The results revealed that the breed of camel had significant $(\mathrm{P}<0.05)$ effect on barrel circumference, heart circumference, body weight and neck length. The Arabi camel was observed had significantly $(\mathrm{P}<0.05)$ higher values of barrel circumference, heart circumference, body weight and neck length compared to the Anafi camel. Moreover, the results revealed that sex of camel was significantly $(\mathrm{P}<0.05)$ affected the most studied traits. The male camels had significantly $(\mathrm{P}<0.05)$ higher values of heart circumference, height at wither, body weight, face length and fore head length than those of female camels; but females had significantly $(\mathrm{P}<0.05)$ longer neck than that of males. The age group had significantly $(\mathrm{P}<0.05)$ influence on all studied measurements except height at hump was insignificantly $(\mathrm{P}>0.05)$ affected. The all tested measurements had increasing trend from $1^{\text {st }}$ age group (3-4 years) to $4^{\text {th }}$ age group (9-10 years), after which some measurements were slightly increased and others were slightly declined.

Key words: Camels, phenotypic measurements, breed, Sudan 


\section{INTRODUCTION}

The world camel number estimates count for 19.4 million heads (FAO, 2003). Sudan camels were estimated to be 3.908 millions contributing to about $11 \%$ of country animal biomass. These figures also represent about $20 \%$ of the world's and also classes Sudan owner ship to be the second after Somalia (30\%), who together owns more than half of the world's- camels. (Ministry of Animal Resources, 2005). In eastern Sudan, camels (Camelus dromedarius) are raised mainly in Butana region and Red Sea coast. In the former, the camel population was estimated around 750.000 head representing more than $25 \%$ of total Sudan camel herd population (Darosa, 2005). The main camel keeping tribes in Butana region are the Lahawiyin, Kawahla, Shukriya, Rashaida, Bija and Bawadra.There are two distinguished types of camels in Sudan, the slow heavy pack or baggage type and the fast light riding or racing camels. The former or baggage type is much heavily built with a balanced appearance of face and hind quarters. The hump is pronounced in well fed animals, shoulder and rump are relatively short and sloping steeply. The hair is often longer and coarse. The legs appear shorter and sturdier with large feet. Live weight of $650 \mathrm{~kg}$ in females and over 800 $\mathrm{kg}$ in males are not uncommon (Schwartz and Dioli, 1992).

Al-Arabi: Which is referred to most pack camels in Sudan. However, Al-Arabi is subdivided into three breed types, the Light Pack which is found west of the Nile and in the area of the Red Sea, where the Hedndiwea, Beni Amer and AL-Omarab tribes keep it, and the big Arabi in the area of Butana where the three tribes of Shokreya, Battahin, and Lahaween exist. The third is the Heavy Arabi camel which is characterized by its heavy weight (over $500 \mathrm{~kg}$ ), big hump, long neck, big head, Roman nose, heavy bones, and sandy grey or fawn color, usually with long hair on the hump and the shoulders (Khouri, 2000).

Al Anaffi: Are characterized by long legs; slender and light body; short back; small, long head; small narrow, upright ears; large, sharp eyes; fine, thin skin; and white color. They are bred by Juhayneya, AL Refaa, Kenana, Shukreya and Kawahla tribes east of Atbara River in eastern Sudan. AL Anafi camels are race and ride camels which are famous for speed $(7-12 \mathrm{~km} / \mathrm{h}$ ), especially for the first $10 \mathrm{~km}$ (Wardeh, 1989). 
The objective of this study is to characterize the two Sudanese ecotypes according to their phenotypic measurements.

\section{MATERIALS and METHODS}

Body measurements data were obtained on 256 camels from two Sudanese ecotypes (Arabi breed) which characterized as pack or baggage type and (Anaffi breed) which identified as racing or riding type. The study area was central of Butana.

A measuring tap $(\mathrm{cm})$ was used for all measures with the exception of height at withers and height at hump tip which were measured with a calibrated stick. The body weights of animals were estimated according to (Boue, 1949) formula. Basic information such as sex, age and breed were recorded for each camel. The age of animals was classified into five groups. The external body measurements recorded was: height at hump: tip from the ground level to the highest point of the hump, height at wither: tip from the ground level to the highest point of the wither, barrel circumference: taken around the abdomen at the last rib, girth circumference: measured around the chest at the fourth ribs, body length: from shoulder point to pin bone, neck length: taken from the point of the shoulder to the base of the neck, face length: measured from tip of the poll to the muzzle, fore head length: measured between the bases of the two ears.

Phenotypic measurements data were subjected to analysis of variance (ANOVA) using the general linear model (GLM). The statistical model used was: $\mathrm{Y}_{i j k l}=\mu+\mathrm{B}_{i}+\mathrm{S}_{j}+\mathrm{A}_{k}+(\mathrm{B} \times \mathrm{S})_{i j}+(\mathrm{B} \times \mathrm{A})_{i k}+$ $(\mathrm{S} \times \mathrm{A})_{j k}+\mathrm{e}_{i j k l}$

Where $\mathrm{Y}_{i j k l}$ is the individual observation for each trait of the animal; $\mu$ is the general mean of each trait; $B_{i}$ : is the fixed effect of the $i$ th ecotype, $S_{j}$ is the fixed effect of $j$ the sex; $A_{k}$ is the fixed effect of $k$ the age group; $(\mathrm{B} \times \mathrm{S})_{j i}$ is the effect of the interaction between sex and ecotype; $(\mathrm{B} \times \mathrm{A})_{i k}$ is the effect of the interaction between ecotype and age group; $(\mathrm{S} \times \mathrm{A})_{j k}$ is the effect of the interaction between sex and age group and $\mathrm{e}_{i j k l}$ is the random error effect associated to the ${ }_{i j k l}$ observations. 


\section{RESULTS}

Influences of breed, sex and age group on the barrel circumference, heart circumference, height at wither and body weight of Butana plain camels were showed in Table 1. However; the effects of the above factors on body length, neck length, face length, fore head length and height at hump were showed in Table 2. The overall means of barrel circumference, heart circumference, height at wither, body weight, body length, neck length, face length, fore head length and height at hump were found to be $227.3 \pm 1.7 \mathrm{~cm}, 172.9 \pm 0.7 \mathrm{~cm}, 180.7 \pm 0.7 \mathrm{~cm}, 376.4$ $\pm 4.7 \mathrm{~kg}, 157.1 \pm 0.8 \mathrm{~cm}, 118.5 \pm 0.8,47.9 \pm 0.2 \mathrm{~cm}, 19.3 \pm 0.1 \mathrm{~cm}$ and $187.3 \pm 1.2 \mathrm{~cm}$, respectively. The analysis of variance results revealed that the breed of camel had significant $(\mathrm{P}<0.05)$ effect on barrel circumference, heart circumference, body weight and neck length, while it had no significant $(\mathrm{P}>0.05)$ influence on height at wither, body length, face length, Fore head length and height at hump. The Arabi camel was observed had significantly $(\mathrm{P}<0.05)$ higher values of barrel circumference, heart circumference, body weight and neck length compared to the Anafi camel. Moreover, the results revealed that sex of camel was significantly $(\mathrm{P}<0.05)$ affected heart circumference, height at wither, body weight, neck length, face length and fore head length; but it was insignificantly $(\mathrm{P}>0.05)$ influenced barrel circumference, body length and height at hump. The male camels had significantly $(\mathrm{P}<0.05)$ higher values of heart circumference, height at wither, body weight, face length and fore head length than those of female camels; but females had significantly $(\mathrm{P}<0.05)$ longer neck than that of males. The age group had significantly $(\mathrm{P}<0.05)$ influence on all studied measurements except height at hump was insignificantly $(\mathrm{P}>0.05)$ affected. The all tested measurements had increasing trend from $1^{\text {st }}$ age group (3-4 years) to $4^{\text {th }}$ age group (9-10 years), after which some measurements were slightly increased and others were slightly declined. The interaction between breed and sex of camel had significant $(\mathrm{P}<0.05)$ effect only height at wither; the males of Arabi camel were higher than females of same breed, while there was no difference observed between males and females of Anafi breed. Also, the interaction between breed and age group was significantly affected only body length. On other hand; the interaction between sex and age group had significant influence on barrel circumference, heart circumference and body weight. The results indicated that height at hump was not significantly $(\mathrm{P}>0.05)$ influenced by any the studied factors. 
Table 1: Means and standard errors of barrel circumference (BC), heart circumference (HC), height at wither (HW) and body weight (BW) for camel of Butana Plain.

\begin{tabular}{|c|c|c|c|c|c|}
\hline $\begin{array}{l}\text { Source of } \\
\text { variation }\end{array}$ & $\mathrm{N}$ & $\begin{array}{c}\mathrm{BC}(\mathrm{cm}) \\
\text { mean } \pm \mathrm{SE}\end{array}$ & $\begin{array}{c}\mathrm{HC}(\mathrm{cm}) \\
\text { mean } \pm \mathrm{SE}\end{array}$ & $\begin{array}{c}\mathrm{HW}(\mathrm{cm}) \\
\text { mean } \pm \mathrm{SE}\end{array}$ & $\begin{array}{c}\mathrm{BW}(\mathrm{kg}) \\
\text { mean } \pm \mathrm{SE}\end{array}$ \\
\hline Breed: & & $*$ & $* * *$ & NS & $* *$ \\
\hline Arabi & 120 & $\begin{array}{c}232.3^{\mathrm{a}} \pm \\
2.4\end{array}$ & $175.6^{\mathrm{a}} \pm 1.0$ & $181.5^{\mathrm{a}} \pm 1.0$ & $390.1^{\mathrm{a}} \pm 6.6$ \\
\hline Anafi & 136 & $\begin{array}{c}222.3^{\mathrm{b}} \pm \\
2.3\end{array}$ & $170.3^{\mathrm{b}} \pm 0.9$ & $179.1^{\mathrm{a}} \pm 0.9$ & $362.6^{\mathrm{b}} \pm 6.4$ \\
\hline Sex: & & NS & $*$ & $*$ & $*$ \\
\hline Male & 122 & $\begin{array}{c}228.3^{\mathrm{a}} \pm \\
2.5\end{array}$ & $174.7^{\mathrm{a}} \pm 1.0$ & $182.4^{\mathrm{a}} \pm 1.0$ & $385.5^{\mathrm{a}} \pm 7.0$ \\
\hline Female & 134 & $\begin{array}{c}226.2^{\mathrm{a}} \pm \\
2.3\end{array}$ & $171.2^{\mathrm{b}} \pm 0.9$ & $178.9^{\mathrm{b}} \pm 0.9$ & $367.2^{\mathrm{b}} \pm 6.3$ \\
\hline Age groups: & & $* * *$ & $* * *$ & $* *$ & $* * *$ \\
\hline $1^{\text {st }}(3-4$ years $)$ & 66 & $\begin{array}{c}209.3^{c} \pm \\
3.5\end{array}$ & $165.6^{\mathrm{c}} \pm 1.5$ & $177.6^{\mathrm{b}} \pm 1.4$ & $321.9^{\mathrm{d}} \pm 9.8$ \\
\hline $2^{\text {nd }}(5-6$ years $)$ & 53 & $\begin{array}{c}218.7^{\mathrm{b}} \pm \\
3.4\end{array}$ & $168.1^{\mathrm{c}} \pm 1.4$ & $178.7^{\mathrm{b}} \pm 1.4$ & $350.2^{c} \pm 9.6$ \\
\hline $3^{\text {rd }}(7-8$ years $)$ & 49 & $\begin{array}{c}237.5^{\mathrm{a}} \pm \\
4.2\end{array}$ & $175.6^{\mathrm{b}} \pm 1.7$ & $178.9^{\mathrm{b}} \pm 1.7$ & $397.4^{\mathrm{b}} \pm 11.7$ \\
\hline $4^{\text {th }}(9-10$ years $)$ & 36 & $\begin{array}{c}238.5^{\mathrm{a}} \pm \\
4.0\end{array}$ & $177.3^{\mathrm{ab}} \pm 1.6$ & $183.3^{\mathrm{a}} \pm 1.6$ & $409.1^{\mathrm{a}} \pm 11.2$ \\
\hline $5^{\text {th }}(\geq 11$ years $)$ & 49 & $\begin{array}{c}232.3^{\mathrm{a}} \pm \\
3.7\end{array}$ & $178.0^{\mathrm{a}} \pm 1.5$ & $184.5^{\mathrm{a}} \pm 1.5$ & $403.2^{\mathrm{a}} \pm 10.3$ \\
\hline Breed*Sex & & NS & NS & $*$ & NS \\
\hline Breed*Age group & & NS & NS & NS & NS \\
\hline Sex*Age group & & $*$ & $*$ & NS & $*$ \\
\hline Overall mean & 256 & $227.3 \pm 1.7$ & $172.9 \pm 0.7$ & $180.7 \pm 0.7$ & $376.4 \pm 4.7$ \\
\hline
\end{tabular}


Table 2: Means and standard errors of body length (BL), neck length (NL), face length (FC), fore head length (FHL) and height at hump (HH) for camel of Butana Plain.

\begin{tabular}{|c|c|c|c|c|c|c|}
\hline $\begin{array}{l}\text { Source of } \\
\text { variation }\end{array}$ & $\mathrm{N}$ & $\begin{array}{c}\mathrm{BL}(\mathrm{cm}) \\
\text { mean } \pm \\
\mathrm{SE}\end{array}$ & $\begin{array}{c}\mathrm{NL}(\mathrm{cm}) \\
\operatorname{mean} \pm \\
\mathrm{SE}\end{array}$ & $\begin{array}{c}\mathrm{FL}(\mathrm{cm}) \\
\text { mean } \pm \\
\mathrm{SE}\end{array}$ & $\begin{array}{c}\text { FHL } \\
(\mathrm{cm}) \\
\text { mean } \pm \\
\text { SE }\end{array}$ & $\begin{array}{c}\mathrm{HH}(\mathrm{cm}) \\
\text { mean } \pm \mathrm{SE}\end{array}$ \\
\hline Breed: & & NS & $*$ & NS & NS & NS \\
\hline Arabi & 120 & $\begin{array}{c}158.3^{\mathrm{a}} \pm \\
1.2\end{array}$ & $\begin{array}{c}120.1^{\mathrm{a}} \pm \\
1.1\end{array}$ & $\begin{array}{c}48.2^{\mathrm{a}} \pm \\
0.3\end{array}$ & $\begin{array}{c}19.5^{\mathrm{a}} \pm \\
0.2\end{array}$ & $\begin{array}{c}188.2^{\mathrm{a}} \pm \\
1.7\end{array}$ \\
\hline Anafi & 136 & $\begin{array}{c}155.8^{\mathrm{a}} \pm \\
1.2\end{array}$ & $\begin{array}{c}117.0^{\mathrm{b}} \pm \\
1.1\end{array}$ & $\begin{array}{c}47.5^{\mathrm{a}} \pm \\
0.3\end{array}$ & $\begin{array}{c}19.2^{\mathrm{a}} \pm \\
0.2\end{array}$ & $\begin{array}{c}186.5^{\mathrm{a}} \pm \\
1.6\end{array}$ \\
\hline Sex: & & NS & $*$ & $* * *$ & $*$ & NS \\
\hline Male & 122 & $\begin{array}{c}158.5^{\mathrm{a}} \pm \\
1.3\end{array}$ & $\begin{array}{c}116.7^{\mathrm{b}} \pm \\
1.2\end{array}$ & $\begin{array}{c}48.8^{\mathrm{a}} \pm \\
0.3\end{array}$ & $\begin{array}{c}19.7^{\mathrm{b}} \pm \\
0.2\end{array}$ & $\begin{array}{c}188.2^{\mathrm{a}} \pm \\
1.8\end{array}$ \\
\hline Female & 134 & $\begin{array}{c}155.6^{\mathrm{a}} \pm \\
1.1\end{array}$ & $\begin{array}{c}120.3^{\mathrm{a}} \pm \\
1.1\end{array}$ & $\begin{array}{c}46.9^{\mathrm{b}} \pm \\
0.2\end{array}$ & $\begin{array}{c}19.0^{\mathrm{a}} \pm \\
0.2\end{array}$ & $\begin{array}{c}186.5^{\mathrm{a}} \pm \\
1.6\end{array}$ \\
\hline Age groups: & & $* * *$ & $*$ & $* *$ & $* *$ & NS \\
\hline $1^{\text {st }}(3-4$ years $)$ & 66 & $\begin{array}{c}150.0^{\mathrm{c}} \pm \\
1.8\end{array}$ & $\begin{array}{c}115.7^{\mathrm{c}} \pm \\
1.6\end{array}$ & $\begin{array}{c}46.9^{c} \pm \\
0.4\end{array}$ & $\begin{array}{c}18.5^{\mathrm{a}} \pm \\
0.3\end{array}$ & $\begin{array}{c}186.2^{\mathrm{ab}} \pm \\
2.5\end{array}$ \\
\hline $\begin{array}{l}2^{\text {nd }}(5-6 \\
\text { years })\end{array}$ & 53 & $\begin{array}{c}157.3^{\mathrm{b}} \pm \\
1.7\end{array}$ & $\begin{array}{c}116.3^{\mathrm{bc}} \\
1.6\end{array}$ & $\begin{array}{c}47.6^{\mathrm{bc}} \pm \\
0.4\end{array}$ & $\begin{array}{c}19.3^{\mathrm{b}} \pm \\
0.3\end{array}$ & $\begin{array}{c}185.8^{\mathrm{ab}} \pm \\
2.4\end{array}$ \\
\hline $3^{\text {rd }}$ (7-8 years $)$ & 49 & $\begin{array}{c}157.3^{\mathrm{b}} \pm \\
2.1\end{array}$ & $\begin{array}{c}116.6^{\mathrm{ab}} \pm \\
1.9\end{array}$ & $\begin{array}{c}47.7^{\mathrm{bc}} \pm \\
0.5\end{array}$ & $\begin{array}{c}19.7^{\mathrm{ab}} \pm \\
0.3\end{array}$ & $\begin{array}{c}185.4^{\mathrm{b}} \pm \\
3.0\end{array}$ \\
\hline $\begin{array}{l}4^{\text {th }}(9-10 \\
\text { years })\end{array}$ & 36 & $\begin{array}{c}159.2^{\mathrm{ab}} \pm \\
2.0\end{array}$ & $\begin{array}{c}122.3^{\mathrm{a}} \pm \\
1.9\end{array}$ & $\begin{array}{c}48.1^{\mathrm{b}} \pm \\
0.4\end{array}$ & $\begin{array}{c}19.4^{\mathrm{ab}} \pm \\
0.3\end{array}$ & $\begin{array}{c}191.3^{\mathrm{a}} \pm \\
2.9\end{array}$ \\
\hline $\begin{array}{l}5^{\text {th }}(\geq 11 \\
\text { years })\end{array}$ & 49 & $\begin{array}{c}161.4^{\mathrm{a}} \pm \\
1.9\end{array}$ & $\begin{array}{c}121.8^{\mathrm{a}} \pm \\
1.7\end{array}$ & $\begin{array}{c}49.0^{\mathrm{a}} \pm \\
0.4\end{array}$ & $\begin{array}{c}19.9^{\mathrm{a}} \pm \\
0.3\end{array}$ & $\begin{array}{c}188.1^{\mathrm{ab}} \pm \\
2.6\end{array}$ \\
\hline Breed*Sex & & NS & NS & NS & NS & NS \\
\hline $\begin{array}{l}\text { Breed*Age } \\
\text { group }\end{array}$ & & $*$ & NS & NS & NS & NS \\
\hline $\begin{array}{l}\text { Sex*Age } \\
\text { group }\end{array}$ & & NS & $*$ & $*$ & $*$ & NS \\
\hline Overall mean & & $\begin{array}{c}157.1 \pm \\
0.8\end{array}$ & $\begin{array}{c}118.5 \pm \\
0.8\end{array}$ & $\begin{array}{c}47.9 \pm \\
0.2\end{array}$ & $\begin{array}{c}19.3^{\mathrm{a}} \pm \\
0.1\end{array}$ & $\begin{array}{c}187.3 \pm \\
1.2\end{array}$ \\
\hline
\end{tabular}




\section{DISCUSSION}

The results showed significant differences between Arabi and Anafi type in the phenotypic measurements, that is attributed to the classification of Anafi as light ridding camels while, Arabi type classified as heavy pack or baggage one (Schwartz and Dioli, 1992). This finding is also in agreement with that reported by Gillespie, (1962) who explained that the Anafi is a slender animal with smallish hump, a marked tucked in abdomen and small feet. These differences between two breeds in body measurements due to pronounced hump of the Arabi type in addition to the much heavily build of the body. The body measurements obtained in this study for Arabi and Anafi breed were lower than that reported by (Ishag et al., 2010; Ishag et al., 2011 ${ }^{\text {; }}$; Ishag et al., 2011 ). The study showed the sex of camel had significant influence on the most studied traits; and the male camels had higher body measurements than the females, this results which was similar to that reported by (Dioli et al., 1992; Mehari et al., 2007; Ishag et al., 2010; Ishag et $a l ., 2011^{\mathrm{b}}$ ); they stated that there is quite distinctive sexual dimorphism in camels, i.e. the male camels is usually taller and of heavier weight than the female. These differences between males and females may reflect differences in the hormonal secretions and their activities in the two sexes. On the other; female camels recorded higher values of neck length compared to the male camels; this could be also attributed to the physiological, anatomical and morphological changes between the two sexes. The age of animal had significantly effect on the all studied traits except height at hump. The all tested measurements had increasing trend from $1^{\text {st }}$ age group (3-4 years) to $4^{\text {th }}$ age group (9-10 years), after which some measurements were slightly increased and other were slightly declined. This results was somewhat is agree with findings of (Ishag et al., 2010; Ishag et al., 2011 ${ }^{\mathrm{b}}$ ); who mentioned that the camels of Sudan reach maturity (growth peak) within 7 to 9 years; after which the different measurements decline. This trend is probably attributed to the increases of the body measurements with the gradually increases in age of the animal till reach the maturity. The height at hump was only body measurement that not significantly affected by breed, sex and age of animal. This is means that the size of hump is influenced by level of feeding; when the level of feeding is good the hump is well developed and gives highest values when take measurement from ground level to the highest point of the hump. 


\section{REFERENCES}

Boué, R. (1949): Weight Determination in the North African Dromedary. Révéué de levage et de medicine veterinaire des pays tropicaux, 3: 13-16.

Darosa, A.E.M. (2005): Studies on Some Camel Production Traits and Health inButana Area, Sudan. Ph.D. Thesis, University of Khartoum, Sudan. P. 135.

Dioli, M.; Schwarz, H.J. and Stimmelmaryr, R. (1992): Management and handling of the camel. In: Schwarz, H.J. and Dioli, M. 1992. The one-humped camels (Camelus dromedarius) in Eastern of Africa: A pictorial guide to diseases, health care and management. Verlag Josef Margraf.

FAO (2003) : Organization of the United Nation. Production Yearbook. Vol. 56 Rome.

Gillespie, I.A. (1962): Riding camels of the Sudan. Sud.J.Vet.Sci., and Anim. Husb., 3: 37-42.

Ishag, I.A.; Eisa, M.O. and Ahmed, M-K.A. (2011 $\left.{ }^{a}\right)$ : Phenotypic Characteristics of Sudanese Camels (Camelus dromedarius). Livestock Research for Rural Development, 23 (4). http://www.1rrd.org/1rrd23/4/isha23099.htm.

Ishag, I.A.; Eisa, M.O. and Ahmed, M-K.A. $\left(2011^{b}\right)$ : Effect of breed, sex and age on body measurements of Sudanese camels (Camelus dromedarius). Australian Journal of Basic and Applied Sciences, 5(6): 311-315.

Ishag, I.A.; Reissmann, M.; Peters, K.J.; Musa, L.M-A. and Ahmed, MK.A. (2010): Phenotypic and Molecular characterization of Six Sudanese camel breeds. South African Journal of Animal Science, 40 (4), 419-426.

Khouri, F. (2000): Camels in Sudan: Ecology, Production Systems, Characterization and Herd Dynamics. The Camel Applied Research and Development Network (CARDN). The Arab Center for the Studies of Arid Zones and Dry Lands (ACSAD). CARDN/ACSAD/ Camel/ P 96/2000. 137 pp.

Mehari, Y.; Mekuriaw, Z. and Gebru, G. (2007): Potentials of camel production in Babilie and Kebribeyah woredas of the Jijiga Zone, Somali Region, Ethiopia. Livestock Research for Rural Development. 19, 4. 
Ministry of Animal Resources, (2005): Department of Statistics and Information, Khartoum-Sudan.

Schwartz, H.J. and Dioli, M. (1992): (EDS) one humped camel in Eastern Africa. A pictorial guide to diseases, health care and management. Verlag Josef Margraf, Germany.

Wardeh, M.F. (1989): Arabian camels: Origin, breeds and husbandry. Al Mallah Publ., Damascus. 500 pp.

Wardeh, M.F. and Ould AL-Mustafa, M. (1990): Camel breed types in the Arab Countries North and West Africa. In: Arab Symp. Camel Husbandry and Diseases and Methods of Their Control. March 24-26,1990. Alger, Algeria. ACSAD /AS/ p105/ 1990, Damascus.

Wilson, R.T. (1984): The camel. Longman Group Ltd. Lssue U.K. 